\title{
«LA RECONSTRUCCIÓN DE LA NACIÓN». HOMOGENEIZACIÓN CULTURAL Y NACIONALIZACIÓN DE MASAS EN LA ESPAÑA FRANQUISTA (1936-1959)'
}

\author{
"The reconstruction of the nation". \\ Cultural homogenization and the nationalization \\ of the masses in Francoist Spain (1936-1959)
}

\author{
FERNANDO MOLINA APARICIO \\ UPV-EHU \\ fernando.molina@ehu.eus
}

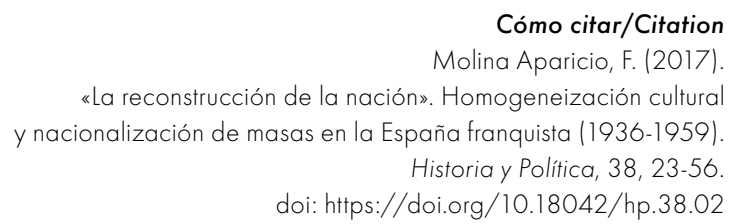

(Recepción: 06/11/2016. Evaluación: 26/12/2016. Aceptación: 07/04/2017. Publicación: 10/11/2017)

Resumen

En este artículo estudio la renacionalización franquista centrándome en dos referentes esenciales: la violencia y la religión. Planteo que el franquismo constituye un ejemplo de Estado homogeneizador impulsado por un etnonacionalismo extremo que tenía como referente cultural la tradición católica. Paso revista a la función de la

Esta investigación se enmarca en los proyectos MINECO HAR2014-51956-P; Grupo de Investigación IT-708-13, y proyecto MINECO HAR2012-37963-C02-02. Quiero agradecer los sugestivos comentarios del editor de este dosier, de quien tanto sigo aprendiendo; las sugerencias recibidas de los revisores y la ayuda que me proporcionaron Antonio Miguez, Claudio Hernández Burgos y José M. Faraldo. 
violencia como instrumento nacionalizador, las magnitudes de la homogeneización cultural alcanzada y el papel que jugó la religiosidad popular como experiencia de la nación franquista. De acuerdo a este análisis propongo que el franquismo logró «reconstruir» la nación española de acuerdo a un proyecto de destrucción del proyecto nacional republicano, experiencia que lo asemeja a otros casos de nacionalización extrema y homogeneización nacional en Europa escasamente atendidos por la historiografía española.

\title{
Palabras clave
}

Nacionalización; homogeneización cultural; etnicidad; Guerra Civil; franquismo.

\begin{abstract}
The Francoist state was founded as a radical solution to the historical confrontation between two great and mutually incompatible visions of the nation: the liberal and the Catholic one. Expanding on the concept of "national homogenization", the article explores the processes of State formation in Eastern Europe as a pattern in the formation of the Francoist nation state. It argues that Francoism was substantially an ethnonationalist political regime that fostered an aggressive nationalization of the masses founded upon political violence and Catholic religion. As a result of this political program, which is analyzed, the Republican national community was dismantled and erased, and Spain was "reconstructed" as a culturally homogeneous Catholic national community.
\end{abstract}

\section{Keywords}

Nationalization of the masses; cultural homogenization; ethnonationalism; Spanish Civil War; Francoism. 
I. INTRODUCCIÓN. II. FRANQUISMO Y NACIONALISMO. III. LA GUERRA COMO INSTRUMENTO NACIONALIZADOR. IV. LAS MAGNITUDES DE LA HOMOGENEIZACIÓN. V. LA «RECONSTRUCCIÓN» DE LA NACIÓN. VI. LA NACIÓN COMO EXPERIENCIA CATÓLICA. VII. CONCLUSIONES. BIBLIOGRAFíA.

\section{INTRODUCCIÓN}

Charles Tilly sugiere que sirve de poco estudiar la violencia si no se ubica en los repertorios de acción donde adquiere centralidad. Lo mismo cabría decir de la religión. En este trabajo estudio el papel jugado por ambas en la primera nacionalización franquista. La forma en que convergen estos factores (violencia, religión, nación) no debe ser entendida solo como un proceso histórico, sino también como fruto de un contexto histórico ${ }^{2}$. La renacionalización franquista culmina un proceso histórico de construcción política de la tradición católica, pero responde a dos contextos inmediatos. Por un lado, el tiempo de radicalización ideológica y crisis del parlamentarismo liberal de entreguerras. Por el otro, el debate sobre la nación que conduce a la Guerra Civil. Esta interpretación conecta la tesis de Tilly sobre la violencia con la de Rogers Brubaker sobre la nación. Este politólogo sugiere que para comprender el nacionalismo y sus políticas institucionales (la nacionalización) debemos investigar los usos prácticos de la categoría «nación» en un tiempo determinado, las múltiples formas en que puede ser percibida, racionalizada y experimentada, de forma que organice el discurso y la práctica política. Lo nacional es algo que «ocurre», que está vinculado a experiencias históricas determinadas. Eso significa que cambia y se transforma, que tiene «existencias» diversas, no una existencia singular y continua ${ }^{3}$. De ahí la idoneidad del concepto de renacionalización, que alude a una nacionalización que cambia de acuerdo no solo al régimen político que la pone en marcha y las culturas políticas que lo definen, sino también al contexto histórico y a la necesidad de actuar sobre individuos ya condicionados por el marco de interpretación nacional ${ }^{4}$. Este planteamiento permite argumentar la cronología de

Malesevic (2013a): 13, 18; (2013b): 99, 105.

Brubaker (1996): 7, 15, 19; Hall (2003): 16.

Quiroga (2011a): 29-30. La importancia del «contexto» en la nacionalización franquista en Hernández Burgos (2017). 
este ensayo. En los años sesenta la renacionalización no fue igual que en los cuarenta, la sociedad sobre la que actuaba no era la misma y el lugar político del que se partía y al que se quería llegar era diferente. Mi interés está en estudiar la primera fase, de guerra y posguerra. El cambio social y la modernización fijan una cesura que no deseo atravesar 5 .

Este texto propone también ubicar lo ocurrido en Espańa en un segundo contexto que tuvo especial incidencia en Europa central y oriental. Estuvo caracterizado por políticas de homogeneización impulsadas por Estados nacionalizadores que favorecieron a unas comunidades etnonacionales frente a otras, estandarizando lenguajes y culturas e imponiéndolos de forma agresiva $^{6}$. En estos procesos intervinieron las nuevas ideologías de masas, caso del fascismo o el comunismo, así como nuevos populismos fascistizados?. En todos tuvieron lugar prácticas de coerción social que descansaron en «mapas mentales» que buscaban hacer coincidir el «territorio imaginado» de la nación con su plasmación etnopolítica de la mano de la guerra, la limpieza étnica, la exclusión política y la represión cultural ${ }^{8}$.

La historiografía en torno a estos fenómenos no convierte los cambios de fronteras que tuvieron lugar en muchos casos en un elemento consustancial del repertorio homogeneizador. $Y$ es que la clave no reside tanto en las transformaciones que se generen en el "continente» de la nación, en el territorio físico, sino en su "contenido", en la cultura que se fije como nacional (y la manera en que es trasladada a la ciudadanía $)^{9}$. Las políticas de nacionalización puestas en marcha, su sentido inclusivo o excluyente, el tratamiento político, social y económico de la diversidad étnica, el recurso a la violencia política y la participación social en ella, todo eso es lo que definirá mejor la conveniencia (o no) de ubicar la experiencia franquista en este contexto europeo poco transitado por la historiografía del franquismo.

La mayoría de los países que se vieron inmersos en estas prácticas homogeneizadoras estrenaban su condición de Estado nación. Debido a ello, las políticas de violencia que tuvieron lugar en ellos buscaban adecuar diversos ethnos a un único demos ${ }^{10}$. En el caso del franquismo, la constitución del

Molina y Pérez (2016): 139-144.

6 La aplicación del paradigma del «Estado nacionalizador» al caso franquista, complementaria de (e interactiva con) la que aquí propongo, en Molina y Pérez (2016): 136-139.

7 Dunn y Fraser (1996); Barkey y Von Hagen (1997), y Snyder (2003).

8 Clark (2013): 20-27; White (2000): 6, 39-40.

9 Como señala Hechter (2000).

10 Mann (2009): 11-21. 
Estado nación era antigua y el demos había ido definiéndose hasta culminar en la etapa republicana, generosa en la proclamación de derechos políticos y de ciudadanía. Sin embargo, el Estado no contaba con un ethnos nacional uniforme ya que existían al menos dos: el liberal y el católico. La tarea que acometió el régimen franquista fue la adaptación del demos al ethnos católico.

A partir de esta premisa reelaboro la pregunta que Snyder se hizo como hipótesis integradora de estos procesos en Europa oriental: la violencia franquista fue causada por el nacionalismo (católico-fascista) pero, a la par, facilitó la nacionalización de las poblaciones y su adecuación al ethnos católico ${ }^{11}$. De acuerdo con este planteamiento, en los siguientes apartados repasaré la historiografía sobre el franquismo y la nacionalización, la función nacionalizadora de la violencia, las magnitudes de la homogeneización cultural alcanzada y el papel que jugó la religiosidad popular como experiencia de la nación franquista. Todo ello me permitirá plantear que el franquismo buscó «reconstruir» la nación espańola siguiendo un paradigma homogeneizador que lo asemeja a otros casos europeos rara vez atendidos por la historiografía española.

\section{FRANQUISMO Y NACIONALISMO}

Los estudios sobre el nacionalismo franquista son muy escasos. Las menciones en obras colectivas no se separan de lugares comunes y de una contemplación historiográfica desfasada respecto del debate teórico internacional ${ }^{12}$. Resulta revelador que compilaciones y síntesis especializadas apenas le dediquen espacio ${ }^{13}$. Los pocos estudios disponibles han descansado en el análisis de sus prácticas discursivas y fundamentos intelectuales, de acuerdo a una rica disociación de sus dos variantes, la fascista y la nacionalcatólica ${ }^{14}$.

Y si los análisis del nacionalismo franquista son escasos, los dedicados a la política ejercida por este resultan aún más testimoniales. La nacionalización, en su condición de práctica política y proceso histórico, es tratada de forma muy general, si bien la mención a su importancia es reiterada. Todos los

\footnotetext{
Snyder (2003): 2.

12 Botti (2013): 114-115.

13 Dos páginas de 462 en de la Granja et al. (2001): 165-166, quince veces menos que las dedicadas a los nacionalismos periféricos en ese periodo. Diecisiete páginas de un total de 1200 (y un único artículo de los ocho que componen la parte dedicada al siglo xx) en Morales et al. (2013).

14 El estudio clásico es Saz (2003), completado con artículos posteriores como Saz (2009).
} 
estudios insisten en que el franquismo fue mucho más que «mero discurso»; fue un esfuerzo de socialización nacional de la población reflejado en políticas educativas, lingüísticas, de memoria colectiva o rituales y en un amplio repertorio de productos trivializadores de la nueva nación. Pero la mayoría de trabajos tienden a centrarse en el «discurso» y a desinteresarse por la política de identidad practicada por un régimen autocalificado como "nacionalista»" Todo esto permite hablar de una historiografía de «murmullos» $\mathrm{y}$ «balbuceos» ${ }^{16}$.

Esta perspectiva encaja con los escasos estudios que profundizan en el papel del catolicismo como nexo de unión (nacionalista) de sus respaldos sociales ${ }^{17}$. También explica el desinterés por interpretar la violencia y su lógica nacionalista: «El franquismo surge de un proceso de violencia estatal masiva que se manifiesta al respecto de las prácticas concretas en una guerra triunfante que le permite imponerse con un número muy elevado de bajas militares y civiles, y unas prácticas de violencia de retaguardia en las que se asesina a miles de personas ${ }^{18}$.

Esta dimensión violenta ha inspirado nuevas categorías con que definirla: práctica genocida, terror, violencia de exterminio, violencia estatal masiva, etc. ${ }^{19}$. Se trata de conceptos que buscan matizar otros ya normalizados en tiempos del franquismo, caso de la «represión», y cuya historia conceptual está aún por hacer ${ }^{20}$. El redescubrimiento de su violencia fundacional abre un fructífero campo en el que reubicar la dictadura militar en el contexto de las violencias políticas (y los procesos de reconstrucción nacional) que tuvieron lugar entre las dos guerras mundiales ${ }^{21}$.

La atención a la violencia masiva impulsada por el bando insurgente permite también revisitar la religiosidad y la función que ambas jugaron en el

15 Box (2013): 903; Núñez Seixas (2006); (2009): 26-30, y Moreno (2014).

16 La metáfora en Botti (2013): 139. Entre estos balbuceos estarían Fuertes (2012); Molina y Pérez (2016); Hernández Burgos (2017), o Moreno Luzón y Núñez Seixas (2017): 227-315.

17 Botti (2013): 111-139.

18 Miguez (2014a): 181. La relación entre violencia y nación es un tema clásico en el debate sobre nacionalismo que es abordado en Moreno (2016), y Malesevic (2013a).

19 Rodrigo (2010); Preston (2011), y Miguez (2014b). El debate historiográfico en Arostegui et al. (coords., 2012).

20 González Calleja (2006), para el concepto y su uso historiográfico, pero sin abordar la experiencia franquista. La necesidad de superar este paradigma conceptual en Miguez (2016): 16-17.

21 Este contexto es abordado en Rodrigo (2014), y su dimensión nacionalista en Kissane (2015). Dos monografías sobre su tiempo de inicio y cierre son: Gerwarth (2016); Lowe (2012). 
proceso de nacionalización de las masas. El franquismo culminó tanto las ensoñaciones nacionalistas del catolicismo español como un proceso nacionalizador que llevaba décadas canalizado por la Iglesia y el catolicismo político y social. La violencia que lo definió contó con el aval de la religión y la nación. Profundizar en la cultura popular católica que interactuó con esta violencia resulta indicado para comprender la naturaleza nacionalista de este régimen pues el catolicismo fue convertido, como en la pasada dictadura primorriverista, en instrumento efectivo de exaltación de la nación oficial ${ }^{22}$.

La nación puso de acuerdo a las diversas familias políticas que sostuvieron la sublevación. Hubo, es cierto, diversos nacionalismos franquistas, cuanto menos dos: el fascista y el católico, y cada uno contaba con una tradición política particular: bien el regeneracionismo y la generación del 98, bien el nacionalcatolicismo desplegado por ideólogos tradicionalistas en el siglo XIX y XX. Sin embargo, ambas tradiciones fueron católicas y se integraron en un único nacionalismo de guerra que definió las políticas del nuevo Estado nación ${ }^{23}$.

Junto con el nacionalismo católico, el otro eje que orientó el consenso entre las familias ideológicas franquistas fue «el rechazo de los valores liberales y el repudio al sistema democrático», las dos señas de identidad del régimen de 1931. El antiliberalismo unía a todas las familias políticas franquistas ${ }^{24}$. La «naturaleza no política» que el nuevo régimen se atribuyó es su resultado. Todas sus variantes ideológicas coincidieron en una negación de la política liberal íntimamente vinculada a la práctica de la violencia política, que dotó de identidad común a todos sus sostenes sociales e ideológicos ${ }^{25}$.

Esta negación resulta lógica desde una perspectiva nacionalista. Los nacionalistas no contemplan la nación como un hecho político (algo que «ocurre»), sino emocional y, en último término, objetivo (algo que «es»). La nación franquista fue imaginada de acuerdo a una narrativa católica, apocalíptica y restauradora. El dolor, la muerte y el sacrificio aparecían en ella como el único camino posible hacia la salvación de la patria y alimentaban un programa político que remitía a la teología católica ${ }^{26}$. La sensación (de corte fascista) del «nuevo comienzo» fue presentada de acuerdo a la figura (de corte tradicionalista) de la «restauración» del orden perdido. Y para esto fue esencial el consenso nacionalista.

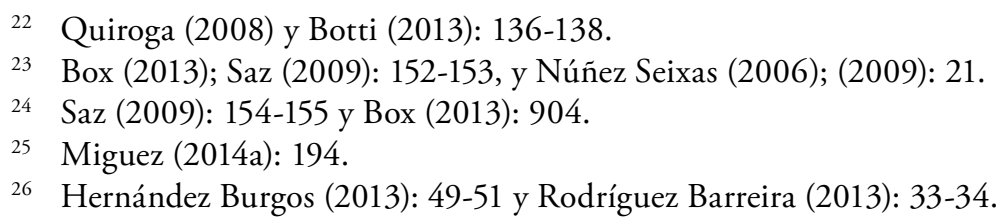


La historiografía del franquismo razonó, hasta principios de este siglo, la lógica del discurso restaurativo franquista y se implicó en una búsqueda de los factores de continuidad histórica. Esta perspectiva del pasado estaba influida por las teorías de la modernización, que convertían el siglo XIX en un tiempo de fracaso liberal simbolizado por guerras civiles, golpes de Estado y revoluciones cuya última fase sería la dictadura militar franquista. Este planteamiento favoreció una interpretación de la Guerra Civil fundada en la lógica narrativa de los excesos cometidos en estos contextos bélicos para interpretar la violencia franquista. La normalización historiográfica de un concepto blando como el de «represión» tuvo sentido en este contexto. La historiografía posterior, impulsada por el debate en torno a la memoria histórica y la condición fascista de este régimen, ha incidido en la "sensación de nuevo comienzo" que pudo canalizar la violencia de los sublevados. Fue la implicación en ella de un amplio sector de la sociedad lo que determinó la incorporación de una nueva generación de «hombres nuevos» al poder, todos con escasa tradición política anterior al golpe de Estado. Esta nueva generación refleja la hondura de la ruptura histórica reflejada por la dictadura ${ }^{27}$.

Consiguientemente, el franquismo recoge y perpetúa una tradición nacional, la católica, pero a la par la reformula de acuerdo a dos parámetros. Por un lado, el contexto europeo marcado por el conflicto ideológico entre extremismos totalizadores y la brutalización de la política (o la politización de la brutalidad). El segundo, la reformulación posibilista que la Iglesia católica hizo de la nación, que facilitó su superposición a la nación fascista, de acuerdo a una lógica interactiva ${ }^{28}$. El proyecto nacionalizador rupturista que se puso en marcha en julio de 1936 descansó en un «nacionalismo negativo» heredado del primorriverismo, que negaba la condición nacional a los oponentes políticos, la razonaba de acuerdo a razones étnicas (especialmente de signo religioso) y patrimonializaba la representación de la "verdadera España». Esta descansaba en una concepción diversa de lo religioso. Mientras los católicos conservadores y tradicionalistas concebían el catolicismo como doctrina de fe, los fascistas lo interpretaban como una estructura de orden asociada a la nación, en donde lo que más interesaba eran los valores de familia, jerarquía, disciplina, autoridad y dogmatismo y cómo canalizaban el mensaje de transformación totalitaria ${ }^{29}$.

El componente proyectivo de este programa nacionalizador negativo tradicionalmente se asocia a la vertiente ideológica fascista, y su moderación en

27 Sirera (2015); Ortega (2006): 264-265; Míguez (2014a): 192-195.

28 Molina y Pérez (2016): 130-134; González Calleja (2009) y (2015): 97; Menozzi (2013): 33-39.

29 Quiroga (2008): 101-103, 113-117, 190, 323-329. 
los primeros ańos de la posguerra se interpreta como un reflejo de su pérdida de hegemonía respecto de la católica en el discurso del régimen. Pero el propio concepto de nacionalcatolicismo lleva implícito un contenido de modernidad que es abstraído por muchos historiadores cautivados por el ampuloso lenguaje teológico con que era presentado ${ }^{30}$. La idea de «misión», trasladada a proyectos específicos como las "misiones populares», refleja el característico recurso nacionalista al oxímoron: no se mandan misiones a donde había fe sino a donde no la había. La trastienda de la tarea nacionalizadora que afrontó la dictadura no fue restaurar un orden (nacional) antiguo, sino implantar uno nuevo.

Consiguientemente, el debate sobre este régimen político debe extenderse a la naturaleza de su proyecto nacionalista, que asumió una tarea titánica: moldear, con el concurso del Estado, dos decenas de millones de personas de acuerdo a una lógica nacionalista que no encontraba respaldo general en esa población. Esta experiencia puede conectarse con la de los países europeos orientales que, en este mismo periodo de tiempo, experimentaron agresivas políticas de nacionalización asociadas a fenómenos de violencia revolucionaria y bélica ${ }^{31}$. Resulta, además, indicado comparar esta dictadura no solo con aquellas contemporáneas que le sirvieron de ejemplo ideológico (caso de la fascista o nazi), sino con otras (caso de las comunistas) que compartieron con ella otros factores que faltan a las primeras: larga temporalidad, experiencias traumáticas de guerra civil, etc. ${ }^{32}$. Estas dictaduras experimentaron, además, el «gran trauma» del cambio social de posguerra, que en España supuso la «gran migración» del campo a la ciudad y la transformación de los usos, costumbres y memoria colectiva de las nuevas generaciones de españoles ${ }^{33}$.

\section{LA GUERRA COMO INSTRUMENTO NACIONALIZADOR}

Los conflictos bélicos resultan una oportunidad para poner en marcha propósitos homogeneizadores de signo nacionalista ${ }^{34}$. Esta potencialidad es aún mayor si el conflicto es de naturaleza civil, pues estos tienden a alimentar procesos estatales de «reconstrucción nacional $»^{35}$. El caso español tuvo como

\footnotetext{
Saz (2003): 311-320; (2009): 155-156; Botti (2013): 136-139.

Brubaker (1997); Gerlach (2010).

Como propone Domper (2014).

Cazorla (2010): 55-132.

Conversi (2012): 453-454; Brubaker (1997): 158.

5 Kissane (2015): 1-14.
} 
origen una insurrección militar golpista que sustentó su discurso nacionalista en dos elementos: la violencia y la religión. Ambos favorecieron la representación de la nación como un hecho político total, algo latente en todos los movimientos nacionalistas. Nacionalismo, religiosidad y violencia presentan una textura narrativa asociativa en su fundamento irracional y totalizador. Además, mediante la violencia el poder de la fuerza se convierte en el único criterio de verdad que acepta el colectivo nacional, que siempre se reivindica como una verdad total, ajena a la libre determinación individual ${ }^{36}$.

La violencia no es un grado o fase del conflicto político que genera el nacionalismo, sino una forma alternativa de plasmar este. Dado que siempre es definida en función de los valores que constituyen lo sagrado resulta fácil que una comunidad le dote de legitimidad nacional de la mano de una religiosidad instrumentalizada como marcador étnico de la nación. Por ello, la religión no anula la "forma nación», sino que la refuerza tanto en su definición narrativa (tramas de sentido) como en su ritual y lenguaje ${ }^{37}$. El recurso a la violencia y la religión favorece la conversión del nacionalismo «banal» en «caliente» de la mano de una narrativa sagrada, que induce a la veneración de los mártires, el sacrificio de los patriotas y el asesinato de los enemigos ${ }^{38}$. Este proceso de superación de una fase nacionalista (banal) por otra (caliente) determina la radicalidad de la experiencia renacionalizadora. Prácticas de coerción y terror institucional o callejero propician una «espiral del silencio» que expulsa la expresión disidente al ámbito privado. En paralelo, se pone en marcha una colonización lingüística del espacio público, de la mano de conceptos y figuras que reivindican una solución violenta al estado de «desposesión» de la identidad y al peligro de desaparición del grupo étnico propio. En el curso de este proceso se difunde una "psicología del odio y la venganza» que favorece la privación de derechos de acuerdo a criterios étnicos. La coerción o la violencia se convierten en una herramienta útil para desembarazarse de los rivales y movilizar a los fieles. Esta psicología «del odio» es una radicalización de la "psicología de las emociones" que caracteriza al nacionalismo ${ }^{39}$. La retórica nacionalista "caliente» niega la democracia liberal, al rechazar la posibilidad del pluralismo y reclamar la privación de derechos de las comunidades disidentes. Los discursos públicos empleados en estos contextos absolutizan el cuerpo social en variables antagónicas: patriotas y antipatriotas, leales y

\footnotetext{
36 Alonso (2008): 11, 36; Halliday (2000): 163-164.

37 Brubaker y Laitin (1998): 425-426, 443-444; Alonso (2008): 15, 25, y Rieffer (2003).

38 Hutchinson (2006): 298; (2005): 115-153; Billig (1995): 39-45.

39 Grigorievs (1996); Billig (1995): 44-45.
} 
traidores, buenos nacionales y malos nacionales. La confusión interna entre Estado y nación, así como entre unas familias ideológicas y otras se compensa con una acentuación de la diferencia con el enemigo, lo que desemboca en una polarización extrema muy adecuada para contextos bélicos.

Todo este proceso fue el que se vivió en la Guerra Civil. Esta supuso la militarización del conflicto normativo entre liberales laicistas y católicos, con sus ocasionales episodios de "guerra cultural». Cuanto más opuestas fueron las convicciones normativas, la frontera entre laicistas y clericales fue mejor delimitada y propició una hostilidad cotidiana, la exclusión del adversario político y la violencia contra este. En los ańos de la República el acceso al poder de grupos políticos laicistas fue visto como una amenaza para la pervivencia de los valores y la moral católicos ${ }^{40}$. El debate se retroalimentó de narrativas de agravios que favorecieron una absolutización del conflicto de acuerdo a parámetros «cuasi-étnicos». Esta lucha cultural por la identidad nacional fue una batalla por la hegemonía política ${ }^{41}$.

En el verano de 1936 republicanos liberales, socialistas, comunistas, sindicalistas marxistas y anarquistas habían sido englobados en la categoría de «rojos» desde las posiciones derechistas católicas que preparaban la insurrección militar. Esta categoría personificaba la tradición nacional que el bando insurrecto rechazaba, de ahí que su identidad se convirtiera en exógena (los «rusos») $)^{42}$. Los años de la República habían propiciado una transformación del proyecto nacionalista «negativo» de los católicos en otro eliminacionista. Una vez la violencia política se intensificó a partir de las elecciones que ganó el Frente Popular, la sangre vertida actuó como una especie de combustible nacionalista ${ }^{43}$. De un proyecto que buscó consensos entre los oponentes políticos, como fue el primorriverista, se pasó a otro, el franquista, que solo entendía el consenso en clave de sometimiento o eliminación ${ }^{44}$.

La propia guerra se convirtió en una "experiencia nacionalista y nacionalizadora»: "De una parte, en una vertiente "positiva", la guerra [fomentó...] la cohesión de quienes pertenecían a la "verdadera España" mediante diferentes estímulos emocionales. De otra, en un sentido "negativo", la contienda quedó transformada en un proceso de desnacionalización de aquellos que no formaban parte de la que se entendía como auténtica comunidad nacional $\aleph^{45}$.

\footnotetext{
40 Louzao (2011): 65; Ramón Solans (2015): 430-436.

41 Hutchinson (2005): 77-78; Billig (1995): 27-28.

42 Sevillano (2007); Núñez Seixas (2006): 245-261, y Miguez (2014b): 21-22, 74, 81.

43 González Calleja (2015); Molina y Pérez (2016): 132-134.

44 Quiroga (2008): 323-329; Miguez (2014b): 97-99.

45 Hernández Burgos (2013): 57.
} 
La práctica de la violencia en la retaguardia franquista fue autónoma del nacionalismo. Pero autonomía no significa independencia sino interdependencia. La guerra fue un reflejo extremo de la nacionalización de la violencia entre facciones políticas que había tenido lugar en los años pasados y constituyó el contexto de oportunidad propicio para impulsar la homogeneización nacional ${ }^{46}$.

\section{LAS MAGNITUDES DE LA HOMOGENEIZACIÓN}

La edad de oro de la homogeneización etno-nacional en Europa tuvo lugar entre el final de la Primera Guerra Mundial y los ańos posteriores a la Segunda, de 1918 a $1948^{47}$. Las políticas homogeneizadoras persiguen la "correspondencia absoluta» entre etnicidad y nacionalidad y ponen en marcha medidas de exclusión entre las que figuran la imposición de una lengua unitaria; la discriminación social por razones étnicas (lingüísticas, religiosas, biológicas); o matanzas y migraciones de poblaciones nativas reconvertidas en «extranjeras». Esta medida extrema, conocida como «limpieza étnica», tiende a ser desplegada en contextos bélicos en que la soberanía del Estado es disputada por grupos políticos en conflicto y surge un nacionalismo que reinterpreta este en clave étnica. El objetivo de estas políticas es afirmar la congruencia entre la identidad cultural y la nacional. De ahí que no se busque solo el asesinato o deportación de los individuos que forman las comunidades perseguidas, sino también la destrucción de sus culturas y tradiciones. Pero el sentido de estas prácticas no es solo destructivo, sino también constructivo. De ahí que en muchos casos amparen la conversión al canon nacional hegemónico de quienes han sufrido la violencia. A mayor componente político del conflicto, mayor intensidad de la violencia que lo acompañará ${ }^{48}$.

La experiencia franquista encaja en este repertorio homogeneizador europeo. La violencia estatal masiva fue canalizada por una variada serie de instrumentos: las detenciones y asesinatos cometidos por fuerzas paramilitares (con la supervisión de autoridades militares); los consejos de guerra instruidos por tribunales militares; la legislación sobre responsabilidades políticas (ley de 9 de febrero de 1939), que declaraba fuera de la ley todos los "partidos y agrupaciones» que formaron el Frente Popular y fijaba las sanciones que se

46 Molina y Pérez (2016): 131-132. La guerra como activadora del nacionalismo en el caso yugoeslavo en Malesevic (2013c): 259-262.

47 Rodrigo (2014); Kramer (2014).

48 Hall (2003): 16; Conversi (2012): 440-441, 455-460, y Mann (2009): 16-18, 22-29, 46. 
aplicarían a quienes hubieran militado en ellos o hubieran simpatizado con sus presupuestos (inhabilitaciones para desempeñar cargos públicos, restricciones a la libertad de residencia y tipificación de las sanciones e incautaciones económicas que se les aplicarían); la legislación sobre represión de la masonería y el comunismo (ley de 1 de marzo de 1940), específicamente destinada a destruir las organizaciones de signo marxista y libertario mediante una política de incautaciones de bienes públicos y penas de prisión; la legislación de depuración de la función pública (leyes de 10 de febrero de 1939 y 18 de marzo de 1939), destinada a depurar los cuerpos de la Administración del Estado y los colegios oficiales (jueces, magistrados, maestros, abogados, médicos), con el fin de impedir la transmisión de la memoria y valores de la República... ${ }^{49}$

Este repertorio punitivo derivó en el tiempo de guerra y posguerra en cerca de 600000 procesados en tribunales militares; 400000 recluidos en prisiones y campos de trabajo; 500000 exiliados fuera de Espańa; cientos de miles de desplazados (la cifra no está contabilizada) a otras provincias, sustancialmente a urbes industriales, por motivos políticos; y cerca de 150000 víctimas mortales estimadas por la acción de paramilitares o de tribunales militares $^{50}$. Los destinatarios de esta violencia estatal fueron el reflejo sociológico de las comunidades ideológicas y políticas que se identificaban con la tradición nacional liberal. Pese a ello, no constituían una comunidad uniforme. A más de la mitad de las víctimas mortales no se le puede atribuir una militancia política concreta. Ello constituye un factor esencial en estas prácticas de violencia categorial. La condición de víctima era marcada por los ejecutores, y podía descansar en terrenos tan volubles como los vínculos afectivos o biológicos con víctimas más razonablemente ideológicas ${ }^{51}$. El programa etnonacionalizador desplegado en complemento de esta violencia fue muy variado: políticas demográficas y de género que perseguían la gestión del cuerpo femenino de acuerdo a un ideario masculinista y católico; incautación de bienes, propiedades y puestos de trabajo de los asesinados o encarcelados; subordinación del espacio público al control moral de la Iglesia y al imaginario del partido único; promoción de un variado tejido legislativo dirigido a restringir los derechos de los vencidos ${ }^{52}$.

49 Sánchez Recio (2015); Miguez (2014b): 114-115.

50 Rodrigo (2008): 125, 137-138; Gómez Bravo y Marco (2011): 95-115; Pla (2007): 242-243, y Marín (2006); (2008).

51 Miguez (2014b): 73-74; Hernández Burgos (2013): 95.

52 Vinyes (2002); (2011); Armenguo y Belis (2005); Blasco (2014); Box (2010); Miguez (2014b): 115-131, y Cazorla (2010): 17-37. 
Toda esta acción derivó en el desmantelamiento del entramado comunitario que sustentaba la identidad nacional republicana. Hasta el año 1931 las organizaciones políticas de republicanos, socialistas, anarquistas y comunistas, sus espacios de sociabilidad y debate, su repertorio de conmemoraciones, ritos e imaginarios simbólicos, la labor educativa y cultural de sus ateneos, casinos y demás agrupaciones, y el discurso de su prensa y academia afín habían canalizado un programa renacionalizador alternativo al institucional. Este es el que alimentó la nacionalización impulsada a partir de esa fecha por el Estado republicano a través de sus canales formales (educación, Ejército, sociedad civil $)^{53}$. Los resultados fueron desiguales, especialmente en su afán secularizador del espacio público, pero revelaron una intensa impregnación nacionalista de la vida cotidiana ${ }^{54}$. Sin embargo, su fundamento no residió en el control de las instituciones, sino en la tradición nacional que estas lograron canalizar. La conformaban, además de símbolos y mitos, determinados valores y principios que habían sido objeto de transmisión intergeneracional como el parlamentarismo, la igualdad ante la ley, la libertad de expresión, el derecho de asociación, el reformismo social, el laicismo, etc. Todo ello era canalizado por un intenso regeneracionismo nacionalista ${ }^{55}$.

El objetivo de la política de violencia y castigo franquista fue la destrucción de la República como parte de un proyecto de mayor calado: la negación histórica de la tradición liberal española ${ }^{56}$. Ello implicó la abolición del conjunto de principios, leyes, instituciones, valores y personas en los que se había apoyado el régimen de 1931: desde una determinada memoria e imaginario liberal-progresista hasta el edificio institucional y legislativo levantado en los años republicanos (las leyes de derechos fundamentales, de divorcio y libertad de enseñanza, de separación entre Iglesia y Estado, de reforma agraria, etc.). También supuso la incautación de los espacios de sociabilidad y organización política (casinos, agrupaciones locales, locales sindicales, casas del pueblo, sociedades culturales y festivas) que habían amparado la reproducción de la memoria republicana ${ }^{57}$.

Una característica de las políticas homogeneizadoras extremas es invadir el espacio privado para imponer en él la nación oficial ${ }^{58}$. La nación republicana era una "comunidad de memoria» cuyo marco básico de reproducción

53 Graham (1996); Radcliff (1997); Holguin (2002), y Salomon (2009).

54 Quiroga (2016); Campos (2016).

55 Sánchez Recio (2015): 40-48; Salomón (2009).

56 Miguez (2014a): 193-194.

$57 \quad$ Di Febo (2006); Duarte (2013): 265.

58 Brewe (2006): 215-216; Wimmer (2006). 
era el hogar ${ }^{59}$. En esta esfera la destrucción de las familias republicanas se orquestó mediante la depredación de sus riquezas y propiedades, el asesinato o encarcelamiento de una parte sustancial de sus miembros masculinos (y, en menor proporción, femeninos), y la migración forzosa de otra parte por el temor a las represalias o la presión de los entornos sociales y afectivos. En este ámbito cobró un papel sensible la violencia contra las mujeres en el plano sexual (violación), económico (expolio de los bienes familiares), local (señalamiento, humillación pública) y judicial (encarcelamiento). Esta empujó a la marginalidad y prostitución a decenas de miles de esposas, madres, hermanas o hijas de asesinados o encarcelados debido a la situación de vulnerabilidad social en que quedaron ${ }^{60}$. Conllevó su criminalización y encarcelamiento por conductas indecentes, mendicidad o pequeña delincuencia y la ocasional apropiación de sus hijos por un entramado asistencial que amparó su entrega a familias católicas. Algo parecido ocurrió con los niños repatriados. La ley de 4 de diciembre de 1941 fijaba que cuando sus padres no fueran localizados y no recordasen su nombre, podían ser inscritos con un nombre distinto en los registros oficiales y entregados a otras familias ${ }^{61}$.

Esta apropiación estatal de menores de familias republicanas era justificada por una concepción étnica de la nación. El discurso nacionalista católico tenía como uno de sus sostenes culturales el racismo y defendía una interpretación biológica de la política. Interpretaba que identidades nocivas como la liberal, marxista o libertaria podían transmitirse genéticamente, condicionadas por el ambiente familiar. El Gabinete de Investigaciones Psicológicas del Ejército, dirigido por Antonio Vallejo Nájera, impulsó investigaciones fundadas en el biologismo científico y la criminología, promoviendo experimentos con presos «rojos» cuyo fin era demostrar la relación entre marxismo y «corrupción» biológica y social. Estas políticas revelan un proyecto destinado a evitar la propensión degenerativa de los niños nacidos en comunidades republicanas. El instrumento fue su reubicación en entornos familiares o asistenciales católicos. Las niñas fueron objeto preferente de estas tutelas estatales, por cuanto su género cargaba con la responsabilidad de la reproducción biológica de la nación ${ }^{62}$.

A estos proyectos eugenésicos se sumó la estigmatización social que afectó a las familias republicanas, especialmente en el marco local: «Las mujeres y los hijos de los vencidos cargaron la mayor parte de las veces con la responsabilidad

59 Duarte (2008): 325; (2009): 99-115.

60 Hernández Burgos (2013): 106-107.

61 Vinyes et al. (2002).

62 Vinyes et al. (2002); Quiroga (2011b). 
del supuesto delito cometido por sus maridos y padres». Los castigos que sufrieron contaron con «la complacencia mostrada por muchos ciudadanos corrientes que [...] se burlaban de los castigados o pensaban que "algo habrían hecho para merecerlo". Mientras, los hijos de los "rojos" tuvieron que convivir con el rechazo y el desprecio sin comprender entonces las razones de ello». Esta violencia de autoridades, vecinos y familiares hizo que la presión sobre las familias de las víctimas (y la propia víctima, si había sobrevivido) fuera asfixiante ${ }^{63}$. Las comunidades locales (hasta entonces los marcos básicos de la política republicana) se convirtieron en espacios de vigilancia y denuncia. Estos comportamientos buscaron conquistar la esfera privada en que se reproduce la nación ${ }^{64}$.

El resultado de estas políticas fueron comportamientos de silencio respecto del trauma vivido y de culpabilidad entre las víctimas por lo que a ellos y sus familiares les había sucedido. El Estado consiguió así crear mentalidades autorreprimidas y fomentar el olvido de la historia y la biografía familiar. La imposición del olvido llegó a la negación del duelo por los asesinados. Su acumulación en fosas anónimas y el silencio que se impuso en los entornos locales, junto con la prohibición de recoger sus restos mortales, celebrar funerales o mostrar luto rompió el entramado de memoria republicana ${ }^{65}$. La inexistencia de un espacio social favorable a la elaboración de un relato común de la experiencia traumática que implica la pérdida de un familiar impide armonizar los recuerdos individuales y construir un sentimiento de pertenencia grupal. La prohibición de cualquier estrategia de recuerdo, salvo el más íntimo, "produjo una cesura en el tiempo de la nación que acabaría por excluir del relato de la misma a quienes se reclamaban republicanos" ${ }^{66}$. Se consiguió, así, la destrucción de la República como comunidad nacional al imposibilitar su reproducción pública o privada.

La comunidad republicana fue convertida en una suma de individuos diezmados física, económica y psicológicamente, afectados por el paso de la cárcel y aislados, incluso en su propio marco familiar. Individuos carentes de instrumentos con los que imaginarse como nación y narrar de acuerdo a ella sus vidas. Solo una vez logrado este grado total de destrucción comunitaria se puso en marcha una política de reasimilación parcial a la comunidad nacional oficial, sustentada en la legislación de perdón, revisión y conmutación de

63 Hernández Burgos (2013): 105 (para las citas); Gómez Bravo (2016): 246-247.

64 Hernández Burgos (2013): 124-129; Molina y Pérez (2016): 135, y Di Febo (2006): 130.

65 Sánchez Mosquera (2008); Hernández Burgos (2013): 107-108; Miguez (2014b): 134-135; Ferrándiz (2014): 18-23, y Frigolé (2003): 29-32.

66 Serrano (2016): 153; Duarte (2008): 329 (para la cita). 
penas que se puso en marcha en los primeros años cuarenta. La reinserción masiva de las víctimas bajo este marco legal refleja el éxito del nuevo Estado en imponer una nueva realidad nacional total y totalizadora ${ }^{67}$.

La intensidad de la acción punitiva sobre el marco familiar republicano resulta congruente con el programa homogeneizador nacionalista. La familia es el núcleo reproductor esencial de la identidad nacional así como su principal agente socializador. El nacionalismo fundamenta su condición de «marco de interpretación» de la realidad social en una trasposición del modelo familiar al de la nación de acuerdo a un repertorio discursivo de «figuras profundas» entre las que destaca el parentesco y el linaje ${ }^{68}$. El pater familias (padre de familia) es el símbolo de una concepción tradicional, masculina, jerárquica y sagrada de la familia que el nacionalismo traslada a la figura del «patriota». Es completada por la de la «madre», que es el instrumento de reproducción de los valores patrióticos asociados al pater familias ${ }^{69}$. La violencia franquista se dirigió primordialmente a hombres que habían formado familia o estaban en condiciones de formarla. Y afectó también a mujeres no solo por su militancia política, sino por su «negligencia» como «madres» por haber parido a (o casado con) «rojos». En ambos casos lo que se logró fue interrumpir el proceso de reproducción de la nación enemiga mediante la destrucción del espacio privado que lo amparaba.

El propósito de esta homogeneización cultural no fue tanto impulsar una comunidad política alternativa a la liberal cuanto una comunidad «no política»: «La forma más activa en que el régimen rechazó esa tradición liberal no fue con los proyectos ideológicos que hicieron suyos algunos de los grupos o familias del franquismo, sino con la práctica de violencia que laminó a la comunidad republicana víctima y con el proceso de implantación a nivel local de la nueva realidad creada por la sublevación $\aleph^{70}$.

El régimen incentivó la incorporación de individuos desprovistos de compromiso e ideología común con los sublevados. E incluso la reversión de una parte de los represaliados al nuevo sistema. Todo este esfuerzo persiguió fijar un ideal de ciudadanía fundado en «la desconfianza hacia la política y el recuerdo de la violencia asociado a las disputas entre partidos, un terreno abonado para el hábito del silencio y el consenso pasivo [...] [y la] resignación [ante] la dictadura como algo dado» ${ }^{71}$.

\footnotetext{
Gómez Bravo y Marco (2011): 269-291.

68 Ozkirimli (2005): 30; Ozkırımlı y Uyan-Semerci (2011): 65-68; Banti (2013): 51.

69 Blasco (2014): 55; Frigolé (2003): 46-47, 49-50, 68-69.

70 Miguez (2014a): 194.

71 Sevillano (2016): 307-308; Gil Andrés (2009): 140-141 (para la cita); Miguez (2014a): 194.
} 


\section{LA «RECONSTRUCCIÓN» DE LA NACIÓN}

He caracterizado la política franquista como etnonacionalizadora. Las características clásicas del concepto de etnicidad encuentran acomodo en la representación franquista de la nación, especialmente la idea de la comunidad de pertenencia que descansa en supuestos criterios objetivos de signo cultural y biológico. La religión es un componente esencial de la etnicidad y esta es habitualmente asimilada en el lenguaje académico a un «grupo religioso» ${ }^{72}$. Convertirla en criterio definidor de la "frontera étnica» con otros grupos es algo que corresponde a una fase de «etnización de la identidad religiosa» que permite dotar a la religión de un nuevo significado de naturaleza nacionalista $^{73}$. De ahí que en el régimen franquista, a partir del referente religioso, se ordenaran y definieran valores de signo biológico (salud, higiene), social (honradez, moralidad, orden) y de clase (pertenencia a estratos sociales medios o altos) que definían a la comunidad etnonacional de prestigio.

Si la nacional es «una identidad narrativa, codificada en relatos sobre quien se es y se quiere ser (y, por tanto, sobre quien no se es o no se quiere ser)", en el primer franquismo estos giraron en torno a por qué hubo de matarse en nombre de la nación ${ }^{74}$. Esto permitió unificar la práctica de la violencia y la narración de la nación en una lógica tautológica típicamente nacionalista: la violencia practicada en nombre de la nación dotaba de sentido a las tramas con que esta era narrada y comunicada. Estas reflejaban la humillación del «pueblo» y justificaban la violencia punitiva contra un enemigo al que se atribuía la «responsabilidad» por la privación de identidad. En todas estas narrativas la violencia y lo sagrado eran los instrumentos que permitían revertir la expropiación de la esencia de la nación y que convertían a los perpetradores en víctimas ${ }^{75}$.

La violencia y lo sagrado fueron razonadas de acuerdo a una narrativa de inevitabilidad reflejada en figuras como la "Cruzada» o el «terror rojo». El primer relato contaba una historia de desposesión de la esencia católica por el liberalismo que habría alcanzado, en la República, el nivel de desastre, al conllevar un intento de eliminación de las raíces nacionales (católicas) con el fin de implantar una tradición exótica marxista, asunto en el que abundaba el segundo relato de la mano de una parafernalia apocalíptica referida al sufrimiento de los católicos durante la guerra. Todo ello era articulado en una

\footnotetext{
Hutchinson y D. Smith (1996): 3 y 5; Mann (2009): 22, y Malesevic (2004): 6.

Yosmaoglu (2014): 171.

La cita en Archilés (2013): 99.

Alonso (2009): 45-46, 28-29.
} 
lógica de suma cero: la prosperidad de España requería la destrucción de la Antiespańa. El sujeto católico al ser enunciado incorporaba automáticamente el antisujeto $\left\langle\right.$ rojo $^{76}$. Este era despersonalizado en estos relatos mediante una representación étnica inspirada en la criminología de la época, que ponía en relación la falta de religiosidad, la extracción social, la ideología política y las características biológicas. Así, tanto las costumbres como la vestimenta o el propio aspecto físico permitían adivinar la condición de «rojo» $»^{77}$. Esta identidad era asociada a una degradación racial y a una condición delictiva, que se asociaba a la militancia libertaria o marxista y a los efectos de una democracia liberal que «al destruir el equilibrio social y mental que garantizaban el orden, ha permitido al crimen, la degeneración y al pecado del pueblo bajo apoderarse de la patria». De ahí que la violencia del «nuevo Estado» buscara perseguir "conductas no solo políticas sino también morales y antisociales, tachadas de dañinas para la comunidad (católica) $»^{78}$.

Esta narrativa de la nación definió el calendario festivo, que canalizó una renacionalización del tiempo. La liturgia conmemorativa estaba compuesta de una sucesión de fiestas que celebraban la violencia en nombre de la nación y de lo sagrado ${ }^{79}$. Modernidad y tradición eran hermanadas en una representación inmóvil de la nación que sintetiza el repertorio narrativo del NO-DO, el noticiario documental que se exhibía en las salas cinematográficas. Su discurso intemporal no perseguía la información sobre actualidad tanto como una representación canónica de la nación: «[Esto] le llevó prácticamente a sustituir la movilización por la desmovilización, la euforia por el consentimiento o, mejor, el asentimiento, y a desplegar un universo de personajes, símbolos, lugares y efemérides que, desprovistos de tiempo y novedad, refrendan lo eterno, lo inmutable de España [...] aquello que en el presente de España revela el ser eterno de la nación ${ }^{80}$.

Cada año era narrado como una sucesión de ceremonias patriótico-religiosas vinculadas al calendario festivo nacionalista y católico, con especial mención a la Navidad y la Semana Santa ${ }^{81}$. Ambas fechas, muy especialmente la segunda, habían adquirido un peso referencial como instrumento de recuerdo de los "caídos» por la causa «nacional». Este simbolismo fue incentivado por la violencia anticlerical, que había interpretado esta celebración como

\footnotetext{
Alonso (2008): 343-364.

Goode (2005); Sevillano (2007), y Cazorla (2007): 292-297.

Las citas en Cazorla (2007): 297, y Sevillano (2016): 306.

Box (2010).

Sánchez Biosca (2014): 181.

81 Sánchez Biosca (2014): 183-186.
} 
"parte del núcleo de la "narrativa de orden" nacionalista». Junto a esa temporalidad cíclica se presentaba una geografía eterna, compuesta por tres lugares de memoria de gran carga simbólica: el Alcázar de Toledo, El Escorial y el Valle de los Caídos. Y, presidiendo este tiempo y geografía inmutables, el jefe del Estado, el gran pater familias, que iría evolucionando desde la construcción épica del tiempo de la guerra al énfasis en su condición de «español corriente», representante de la comunidad «no política» que constituía la nación ${ }^{82}$.

El lenguaje del NO-DO sintetiza el proyecto impulsado por las «agentes nacionalizadores más institucionales» (educación pública, Iglesia, organizaciones de encuadramiento político, medios de comunicación y servicio militar) y banalizado en el espacio público, en las banderas desplegadas en las festividades litúrgicas y patrióticas, las colgaduras y saludos brazo en alto generalizados en los contextos festivos o las ceremonias litúrgicas católicas ${ }^{83}$. El monumentalismo patriótico y el nuevo callejero celebraban una memoria católica que resonaba con mayor fuerza en la medida que, por primera vez, no encontraba incómodo eco en otra alternativa. Esa memoria fue materializada en los monumentos a Francisco Franco y a los mártires del «alzamiento nacional». También en la multitud de edificios religiosos en estado ruinoso por la guerra o la destrucción anticlerical. Estas ruinas y las construcciones levantadas sobre ellas concitaron movimientos de peregrinación y procesión religiosa destinados a evocar el «terror rojo». Toda esta nueva memoria era presidida por la Cruz de los Caídos, el monumento conmemorativo del martirio nacional que articulaba la vida local de los espańoles y era punto de confluencia de todo acto público y festivo ${ }^{84}$.

\section{LA NACIÓN COMO EXPERIENCIA CATÓLICA}

La banalización de la nación fue también canalizada por la práctica religiosa: la reespañolización marchó siempre unida a la recatolización ${ }^{85}$. Esta fue diseńada desde una perspectiva misional. Los episodios de iconoclastia ocurridos durante la República y los masivos asesinatos de sacerdotes, religiosos y militantes católicos durante la guerra incentivaron un discurso expiatorio que se generalizó en los años de posguerra. Presentaba la guerra como un castigo enviado por Dios que exigía un programa de actos de contrición y desagravio

\footnotetext{
82 Richards (2005): 257, 261 (para la cita); Sánchez Biosca (2014): 186-191.

83 El lugar del NO-DO en este repertorio nacionalizador en Hernández Burgos (2017).

84 Box (2009); Michonneau (2014); Sánchez Erauskin (1994): 45-46, y Hernández Burgos (2013): 110-113.

85 Hernández Burgos (2017).
} 
(misas, procesiones, oraciones y rosarios nocturnos). Las instituciones religiosas, con su recuperada función educativa; la educación pública, presidida por el crucifijo perseguido; el espacio del trabajo, con la asignación de consiliarios a las empresas, la inserción de las organizaciones especializadas de la Acción Católica y el envío de trabajadores a las casas de ejercicios espirituales; y el ocio, con el control y la censura de las actividades festivas y lúdicas, fueron los ámbitos públicos y semipúblicos en donde cobró forma esta tarea. La penitencia pública y su retórica, tanto discursiva como gestual, fue asumida por la población: arrodillarse o cubrirse la cabeza ante el paso de imágenes religiosas, santiguarse durante un acto político, llevar objetos religiosos en las procesiones eran prácticas expiatorias teñidas de sentido patriótico ${ }^{86}$. El nuevo diseño urbanístico también fue un marco de materialización del proyecto recatolizador: las intervenciones practicadas en las «regiones devastadas» y los proyectos de reforma de las ciudades fueron elaborados de acuerdo con un programa de ordenación del espacio de impronta católica, con edificios de viviendas de pocos pisos que formaban bloques presididos o flanqueados por iglesias que perseguían la resacralización del territorio de la nación ${ }^{87}$.

Este proyecto «restaurativo» sintonizó con las creencias, miedos y anhelos de sectores de la sociedad que no concebían una nación diferente a la definida por la tradición nacionalcatólica: «Quienes en época republicana habían vivido las quemas de templos, la prohibición de las procesiones o las dificultades para asistir a misa recibieron el franquismo con sentimientos de alivio y esperanza. Al fin y al cabo, habían considerado la República y la democracia como la amenaza de que su "ordenado" mundo pudiera desmoronarse»"

Durante la guerra fueron ciudadanos corrientes los que encalaron muros con imágenes religiosas para ocultarlas de los ánimos iconoclastas, enterraron las figuras sagradas y recogieron los restos de las destruidas. La recuperación de los cristos y vírgenes y la reconstrucción de las ermitas y parroquias destruidas constituyeron «experiencias de nación». Estas «experiencias» reflejan la construcción cotidiana de la nación como narrativa de sentido que surge de su interacción con otras «identidades de clase, de género y étnicas [...]. Estas identidades, a su vez, no son previas ni fundamentales, frente a la de nación, sino que actúan en planos distintos pero equiparables». La mención a las «identidades étnicas» convierte la religiosidad en un oportuno mecanismo productor de experiencias nacionales ${ }^{89}$.

\footnotetext{
Hernández Burgos (2013): 114-115, 117.

Miguez y Molina (2016).

Hernández Burgos (2013): 115.

Archilés (2013), 105 (para la cita); Moreno Seco (2002).
} 
La nacionalización franquista culminó la apropiación patriótica de las liturgias y devociones populares que había hecho la tradición católica en el tiempo de la guerra cultural. Imaginería mariana y de santos, placas y efigies del Sagrado Corazón, rosarios y escapularios poblaban un espacio público marcado por hornacinas de la Virgen y los santos en calles y fábricas y cristos crucificados en las escuelas y casas... España era un lugar en el que «se nace, se vive, se juega, se sufre, se ama, se trabaja entre imágenes». A estas imágenes se les rendía culto en el hogar y las más preciosas eran trasladadas, en las zonas rurales, de casa en casa, para su cuidado y la limpieza espiritual de la familia. Articulaban la vida local, el calendario festivo y la ocupación de la calle con motivo de las procesiones, coronaciones y demás liturgias que les rendían culto. Fueron objeto de consumo estandarizado, especialmente las vinculadas a las nuevas devociones generadas por la respuesta católica al desafío secularizador, caso de la Inmaculada Concepción, el Cristo Rey o el Sagrado Corazón de Jesús, que canalizaron la autoidentificación nacional frente a laicistas republicanos o marxistas ${ }^{90}$.

Esta nueva imaginería religiosa enriqueció el repertorio devocional local con nuevas peregrinaciones, procesiones, misas y oficios. Asimismo, vehiculó procesos de socialización como las misiones populares dirigidas por los obis$\operatorname{pos}^{91}$. Y favoreció un hermanamiento entre la identidad familiar, la regional y la nacional. El caso del Sagrado Corazón de Jesús es significativo en tanto que devoción que impulsó la industrialización de la imaginería católica de acuerdo a un ideal nacional: «Construyó un entramado piramidal que comenzaba con una base que se fundamentaba en lo personal y lo familiar, y que [...] [escapa] del ámbito de lo privado para manifestarse en todos los aspectos de la vida pública [...]. En la cumbre de la pirámide, o concretamente en el centro geográfico español [...] el monumento del Sagrado Corazón del Cerro de los Ángeles ${ }^{92}$.

Estas imágenes fueron paseadas en las primeras fases de la guerra en un movimiento callejero alegórico de la patria católica. Simbolizaban un espacio de sociabilidad esencial como era la parroquia, concebida como una "pequeña cristiandad» que permitía imaginar la nación desde la esfera local. De ahí que se le transfirieran ideales absolutos (orden, unidad, armonía) que la convertían en una comunidad moral. Era un espacio santificado por lugares de oración y peregrinaje que transmitían «la expresión de un creer, la memoria de una

90 Louzao (2015): 464-465 (para la cita); Louzao y Rodríguez Lago (2016): 74; Ramón Solans (2015): 447-453.

91 Moreno Seco, (2002); Louzao (2015): 466-467.

92 Louzao (2010): 187. 
continuidad y la referencia legitimadora a una versión de esta memoria, es decir, lo que se conoce como la tradición». La participación activa de los párrocos en la rebelión militar, en el señalamiento de los vecinos «rojos» y en la legitimación del nuevo orden (de acuerdo a las lógicas del "perdón» y la "compasión») fue tanto o más importante que la de los vecinos que con ellos colaboraron a la hora de convertir las parroquias en el motor del proyecto recatolizador ${ }^{93}$.

El proyecto homogeneizador católico buscó crear una comunidad nueva siguiendo la mecánica narrativa del nacionalismo, el «andar del cangrejo», consistente en la invención de un pasado sońado que marca el discurso de la nación mediante la imposición de unas «imágenes del recuerdo» que buscan aglutinar el cuerpo social ${ }^{94}$. El propósito de esta «reconstrucción de la nación» fue construir una nueva comunidad política desde planteamientos centrados en la exaltación étnica de lo local, lo regional y lo nacional.

\section{CONCLUSIONES}

El texto que aquí presento es abierto, algo lógico dada su naturaleza ensayística y su sostén en fuentes secundarias. El planteamiento general que he defendido es que el programa nacionalizador franquista tuvo como fundamento la violencia y la religión y favoreció un proceso de «reconstrucción nacional» de España que casa perfectamente con los proyectos nacionalizadores más agresivos de aquel tiempo en Europa. A partir de esta idea central he incidido en el carácter étnico del nacionalismo franquista y de la cultura política católica que dio sentido a su maquinaria nacionalizadora, en donde las diferencias ideológicas tuvieron un peso secundario. Igualmente he planteado el sentido más proyectivo que retrospectivo que tuvo este programa homogeneizador y la derivación del mismo a la destrucción total del proyecto nacional republicano. La elección que he hecho de este tema no presupone ninguna contemplación angélica de las prácticas de violencia que tuvieron lugar en la España republicana ${ }^{95}$. Como advierte Michael Mann, la asociación del demos a la clase es tan potencialmente genocida como al

93 Ugarte (1998): 9-18; Louzao (2010): 186; Miguez (2014b): 103, y Martínez Sánchez, 2016.

94 Thiesse (2010): 158-159; Langewische (2012): 57.

95 La insuficiencia de términos como «violencia revolucionaria» para caracterizarla, no menor que la de «represión franquista» en Miguez, (2014b): 17, 22. 
ethnos ${ }^{96}$. Con todo, mi interés estaba, de acuerdo con el dosier, en definir la relación entre violencia, nacionalismo y etnicidad que tuvo lugar en la España franquista.

En su reseña de un reciente libro de Paul Preston, Timothy Snyder propone no leer lo acontecido en Espańa como una singularidad fruto de un tortuoso pasado. Frente a la tesis particularista de Preston, enfrascado en levantar una enciclopédica acta del horror encaminada a formalizar las responsabilidades de los militares golpistas, Snyder propone leer lo ocurrido en España desde la óptica de la experiencia histórica en el contexto de los regímenes de Hitler y Stalin. En ella se vivió la consecuencia de la aplicación de las tácticas colonizadoras imperialistas en el mismo continente que las había impulsado, bien contra poblaciones extranjeras o bien contra los propios nacionales extranjerizados por discursos totalizadores de nación o clase. Su propuesta da pie a otra interpretación complementaria: que detrás de esa experiencia histórica existiera, en el caso español, un proyecto de «reconstrucción» de la nación tal y como él mismo lo ha definido para otras partes de Europa: la interacción entre Estado y homogeneización nacional de la mano de la guerra y la limpieza étnica ${ }^{97}$.

Snyder escribe desde una reconocida falta de familiaridad con la historia española, pero esta condición puede guardar un lado positivo si se tiene en cuenta la metáfora de los «secretos» que los «buenos patriotas» aprenden a no contar en el marco nacional de igual manera que "los buenos chicos» hacen en el marco familiar. De acuerdo con esta metáfora, la nación actúa como una familia que ampara el secreto ante determinados asuntos que resultan incómodos de afrontar ${ }^{98}$. Lo que Snyder revelaría es un secreto incómodo: que lo ocurrido en la Guerra Civil y la dictadura encaja con lo que en otras partes de Europa estaba pasando y no es fruto de ninguna romántica particularidad.

En las experiencias históricas de homogeneización etnonacional que tuvieron lugar en la Europa central y oriental entre las décadas de 1910 y 1940, la violencia masiva favoreció el exterminio o apartamiento de comunidades que habían sido enajenadas de la nación. Esta enajenación no fue automática sino el resultado de un proceso de confrontación etnopolítica que en España remite al conflicto normativo entre laicismo y clericalismo. En la Europa central y oriental la destrucción fue el último estadio de un proceso histórico de discriminación, exclusión o separación de comunidades étnicas

\footnotetext{
Mann (2009): 14.

Snyder (2012): 2003: 2, 5.

Ozkirimli y Uyan-Semerci (2011): 72-73.
} 
no asimiladas a la nación oficial ${ }^{99}$. Esta fase de exterminio tuvo lugar en un contexto bélico caracterizado por la ansiedad ante el peligro de invasión externa que facilitara el «enemigo interior». Todo ello encaja en la experiencia española, en donde los «rojos» fueron identificados bien como extranjeros invasores o como una quinta columna de estos, y la violencia fue practicada de acuerdo a inspiraciones sagradas ${ }^{100}$.

El recurso a la violencia extrema permitió a sus ejecutores el borrado de la memoria que no concordaba con la verdad narrativa de su nación y redefinir la conexión con el pasado de la comunidad nacional «reconstruida» en torno a una única memoria colectiva. En Europa central u oriental el borrado de la memoria de un pasado diverso incluyó prácticas extremas como renombrar territorios depurados étnicamente, negar el derecho al recuerdo de los asesinados, eliminar los símbolos de la comunidad destruida y/o asimilada y normalizar la amnesia y el silencio respecto de los crímenes cometidos. Salvo la primera de estas prácticas, las otras fueron compartidas por la experiencia nacionalizadora franquista.

Esta también compartió el papel central que en esas experiencias homogeneizadoras se confirió a narrativas de identidad que legitimaban la violencia en tanto que respuesta a una violencia previa que habría amenazado la supervivencia de la nación o como la parte culminante de un "conflicto histórico" en el que "todos fueron culpables» ${ }^{101}$ Cuando la violencia se convierte en la práctica central de una comunidad que se imagina como nacional, podemos hablar de "comunidades de violencia» o de "sociedades extremadamente violentas». Sus miembros la celebran como un instrumento de expiación pública de los males de la nación y la practican frente a individuos cuya identidad es creada de acuerdo a rasgos heréticos que lo colocan fuera del bien común. Es la exclusión y destrucción de este colectivo lo que dota de sentido nacional a la comunidad propia. La nación franquista «reconstruida» se sostuvo gracias a la violencia fundacional que unió a "perseguidores» (quienes mataron y confirieron lógica a su violencia; quienes se lucraron con los puestos de trabajo y riquezas robados; quienes delataron y colaboraron con las nuevas autoridades), a quienes miraron para otro lado o mediaron para suavizarla (pero no la cuestionaron, por lo que le dotaron de sentido y legalidad) y a una parte de sus víctimas, que asumieron la culpa y buscaron acomodo en la nueva sociedad.

Un debate inevitable que mencionar es el de la efectividad (el éxito o fracaso) del programa nacionalizador de la dictadura. Ya hace tiempo se

99 Conversi (2012): 469.

100 Molina y Pérez (2016): 136-137.

101 Billig (1995): 37-39. 
señaló el carácter ambivalente del mismo, más débil en su capacidad unificadora y de imposición de una cultura política uniformizadora, pero más potente en «lo que respecta a la difusión e impregnación generalizada de un sentimiento de identidad colectiva "espańola" y supralocal, con todos los problemas de legitimidad que se quieran ${ }^{102}$. De esta ambivalencia se han desprendido dos interpretaciones. Una es que el franquismo terminó fracasando en sus objetivos como reflejaría la pervivencia y reforzamiento final de los nacionalismos subestatales, la crisis movilizadora del nacionalismo español en el proceso de transición a la democracia y la posición dubitativa de las izquierdas espańolas ante este en el posterior tiempo democrático ${ }^{103}$. Recientemente esta apreciación ha sido matizada mediante una mayor atención a la dimensión banal y cotidiana del nacionalismo. De acuerdo a esta tesis alternativa, la nacionalización franquista habría fracasado en su dimensión «autoritaria», pero no en su carácter «renacionalizador» pues es necesario «diferenciar entre la efectividad de la nacionalización en el sentido más básico — transmisión de la idea de pertenencia a la nación espanola- y la efectividad de la nacionalización específicamente franquista - transmisión de los concretos contenidos asociados a los nacionalismos franquistas»-. Este éxito relativo habría permitido que los mecanismos informales de nacionalización (esfera pública, cultura popular y de masas, festividades e identidades de signo subestatal) siguieran "saturados de espańolidad» tanto en los años finales del régimen como en el tiempo posterior de la democracia ${ }^{104}$.

Resulta plausible encontrar en la Espańa del final de la dictadura una pulsión de nacionalismo banal que recorre todas sus esferas, tanto públicas como semipúblicas. Sin embargo, en los ańos setenta y ochenta miles de inmigrantes «banalmente» españoles y de sus descendientes fueron «renacionalizados» como vascos o catalanes, votaron a partidos nacionalistas locales y abandonaron cualquier identificación exclusiva o compartida con la nación española. La nacionalización franquista, pues, pudo ser exitosa en su capacidad de banalizar la nación oficial, pero no parece que lo fuera en afianzar una cultura que asegurara su exitosa reproducción. De acuerdo con lo que he defendido en este texto, la «reconstrucción nacional» hizo difícil disociar el continente nacional españolista del contenido cultural específicamente franquista. Descansó en la reinvención de una etnicidad católica que hermanó las

102 Núñez Seixas (1999): 118. Un análisis de estas paradojas en Moreno Luzón y Núñez Seixas (2017): 275-315.

103 Núñez Seixas, (2007a): 87; (2007b): 225-227.

104 Fuertes (2012): 281; Rueda (2014), y Hernández Burgos (2017). 
diferentes familias ideológicas y dotó de homogeneidad a la cultura política franquista ${ }^{105}$. Esta etnicidad entró en crisis con el cambio social que tuvo lugar en los ańos sesenta. En este tiempo la secularización generó un proceso de «erosión nacional» debido a la identificación exclusiva que el catolicismo había logrado con el nacionalismo español ${ }^{106}$.

En todo caso, el debate historiográfico debe derivar hacia una mejor definición de las magnitudes que definen categorías como éxito o fracaso de acuerdo a sus particulares contextos temporales. No fue el peso de la nacionalización banal en el tardofranquismo y la transición democrática el que marcaría ese éxito o fracaso, sino la capacidad que tuvo el Estado de la guerra y la posguerra para redefinir el universo de las identidades territoriales españolas y destruir cualquier opción alternativa al proyecto nacional católico-fascista. La laminación de la memoria de la República y de su identidad nacional facilitó el desapego de las nuevas generaciones, impulsado por una política del recuerdo que estigmatizó este régimen derrotado ${ }^{107}$. Esto permitió que se convirtiera en un mito vacío en el que se acomodaba cualquier proyecto alternativo a la dictadura, pero siempre desconectado del sentido nacionalista (español) que había tenido. Su componente cívico y pluralista, más orientado a referentes individuales y de derecho que colectivos e históricos, había sido también laminado. De ahí que la lógica de la identidad territorial se derivara, cuando el proyecto nacionalizador franquista comenzó a vacilar, a entidades etnorregionales y etnonacionales, los "pueblos» y «nacionalidades» luego consagrados por la cultura política de la transición democrática y la propia Constitución de 1978. La escasa historiografía sobre la dimensión nacionalista de la experiencia republicana (y quiénes la han elaborado, generalmente historiadoras no españolas) es un reflejo de este apartamiento de la República de la identidad nacional en el propio plano académico $^{108}$. La actual conversión de la bandera tricolor republicana en icono kitsch de la rebeldía política juvenil y nacionalista periférica refleja hasta qué punto la República ha sido reconvertida en un espacio vacío en el que verter no solo la crítica del régimen de 1978, sino también un desconocimiento nada casual de lo que significó como proyecto truncado de nación española.

105 Saz (2015): 51, sostiene que esta homogeneidad fue imposible desde una perspectiva ideológica. Lo que aquí defiendo es que fue cultural, de signo católico.

106 Molina y Pérez (2016): 139-144.

107 Humlebaek (2006).

108 Los estudios clásicos son: Graham (1996); Radcliff, (1997); Holguin (2003). El más reciente y que rompe (parcialmente) esta observación, es Campos (2016). 


\section{Bibliografía}

Alonso, M. (2008). Razones enalbadas. Retórica de la violencia politica [tesis doctoral]. UNED.

- (2009). El síndrome de Al-Andalus. Relatos de expoliación y violencia política. En J. Casquete (ed.). Comunidades de Muerte (pp. 19-54). Madrid: Anthropos.

Archilés, F. (2013). Lenguajes de nación. Las «experiencias de nación» y los procesos de nacionalización. Ayer, 90 (2), 91-114.

Armengou, M. y Belis, R. (2005). El convoy de los 927. Barcelona: Plaza y Janes.

Arostegui, J., Marco, J. y Alonso, G. (coords.) (2012). De genocidios, holocaustos, exterminios. Sobre los procesos represivos en España durante la Guerra Civil y la dictadura. Hispania Nova, 10. Disponible en: http://hispanianova.rediris.es/10/dossier.htm.

Banti, A. (2013). El discurso nacional italiano y sus implicaciones políticas. En F. Archilés, M. García Carrión e I. Saz (eds.). Nación y nacionalización. Una perspectiva europea comparada (pp. 49-65). Valencia: Unibersitat de València.

Barkey, K. y Von Hagen, M. (eds.) (1997). After Empire. Multiethnic societies and nation-building. Boulder: Westview Press.

Billig, M. (1995). Banal nationalism. Londres: Sage.

Blasco, I. (2014). Género y nación durante el franquismo. En S. Michonneau y X. M. Núñez Seixas (eds.). Imaginarios y representaciones de España durante el franquismo (pp. 49-71). Madrid: Casa de Velázquez.

Botti, A. (2013). Iglesia y nación en los años de entreguerras en la historiografía del posfranquismo. En A. Botti, F. Montero y A. Quiroga (eds.). Católicos y patriotas. Religión y nación en la Europa de entreguerras (pp. 111-139). Madrid: Sílex.

Box, Z. (2009). Poder creador de la muerte y el dolor: la consagración de los lugares del martirio en el régimen franquista. En J. Casquete (ed.). Comunidades de Muerte (pp. 55-93). Madrid: Anthropos.

(2010). España Año Cero. La construcción simbólica del franquismo. Madrid: Alianza.

(2013). El nacionalismo español durante el franquismo (1939-1975). En A. Morales, J.

P. Fusi y A. de Blas (dirs.). Historia de la nación y del nacionalismo español. Madrid:

Galaxia Gutemberg.

Brewer, J. D. (2006). Memory, truth and victimhood in post-trauma societies. En G. Delanty y K. Kumar (eds.). The Sage Handbook of Nations and Nationalism (pp. 214-224). Londres: Sage. Disponible en: https://doi.org/10.4135/9781848608061.n19.

Brubaker, R. (1996). Nationalism Reframed. Nationhood and the National Question in the New Europe. Cambridge: Cambridge UP. Disponible en: https://doi.org/10.1017/ CBO9780511558764.

- (1997). Aftermaths of Empire and the Unmixing of Peoples. En K. Barkey y M. Von Hagen (eds.). After Empire. Multiethnic societies and nation-building (pp. 155-180). Boulder: Westview Press.

Brubaker y Laitin, D. (1998). Ethnic and Nationalist Violence. Annual Review of Sociology, 24, 423-452. Disponible en: https://doi.org/10.1146/annurev.soc.24.1.423.

Campos, L. (2016). Celebrar la nación. Conmemoraciones oficiales y festejos durante la II República. Madrid: Marcial Pons. 
Cazorla, A. (2007). Patria Mártir: los españoles, la nación y la Guerra Civil en el discurso ideológico del primer franquismo. En J. Moreno Luzón (ed.). Construir España. Nacionalismo español y procesos de nacionalización (pp. 289-302). Madrid: CEPC.

- (2010). Fear and Progress. Ordinary Lives in Franco's Spain. Oxford: Wiley-Blackwell.

Clark, Ch. (2013). The Sleepwalkers. How Europe went to war in 1914. Londres. Penguin Books.

Conversi, D. (2012). Nación, estado y cultura. Por una historia política y social de la homogeneización cultural. Historia Contemporánea, 45, 437-481.

De la Granja, J. L., Beramendi, J. y Anguera, P. (2001). La España de los nacionalismos y las autonomías. Madrid: Síntesis.

Di Febo, G. (2006). La cancelación de la República durante el Franquismo. En A. Egido (ed.). Memoria de la Segunda República. Mito y realidad (pp. 117-134). Madrid: Biblioteca Nueva.

Domper, C. (2014). La otra cara de las urnas. Elecciones, dictaduras y Guerra Fría en Europa. Propuestas para un marco conceptual. Rúbrica Contemporánea, 3 (5), 45-69.

Duarte, A. (2008). Sin historia no hay republicanos. Historia Contemporánea, 37 (2), 321-342.

(2009). El otoño de un ideal. El republicanismo histórico español y su declive en el exilio de 1939. Madrid: Alianza.

(2013). El republicanismo. Una pasión politica. Madrid: Cátedra.

Dunn, S. y Fraser, T. G. (1996). Introduction. En S. Dunn y T. G. Fraser (eds.). Europe and Ethnicity. The First World War and contemporary ethnic conflict (pp. 1-9). Londres, New York: Routledge.

Ferrándiz, F. (2014). El pasado bajo tierra. Exhumaciones contemporáneas de la Guerra Civil. Madrid: Anthropos.

Frigolé, J. (2003). Cultura y genocidio. Barcelona: Unibersitat de Barcelona.

Fuertes, C. (2012). La nación vivida. Balance y propuestas para una historia social de la identidad nacional española bajo el franquismo. En I. Saz y F. Archilés (eds.). La nación de los españoles. Discursos y prácticas del nacionalismo español en la época contemporánea (pp. 279-300). Valencia: PUV.

Gerlach, Ch. (2010). Extremely Violent Societies. Mass Violence in the Twentieth-Century World. Cambridge: Cambridge UP. Disponible en: https://doi.org/10.1017/ CBO9780511781254.

Gerwarth, R. (2016). The Vaquished. Why the First World War Failed to End. Londres: Penguin.

Gil Andrés, C. (2009). La zona gris de la España azul. La violencia de los sublevados en la Guerra Civil. Ayer, 76 (4), 115-141.

Gómez Bravo, G. (2016). La redención de los vencidos y los extraviados. Los presos y sus familias. En F. Montero y J. Louzao (eds.). La restauración social católica en el primer franquismo, 1939-1953 (pp. 235-250). Granada: Comares.

- y Marco, J. (2011). La obra del miedo. Violencia y sociedad en la España franquista. Barcelona: Península.

González Calleja, E. (2006). Sobre el concepto de represión. Hispania Nova, 6. Disponible en: http://hispanianova.rediris.es/6/dossier/6d022.pdf. 
- (2009). Experiencia en combate. Continuidad y cambios en la violencia represiva (1931-1939). Ayer, 76 (4), 37-64.

(2015). Cifras cruentas. Las víctimas mortales de la violencia sociopolítica en la Segunda República española. Granada: Comares.

Goode, J. (2005). Corrupting a Good Mix: Race and Crime in Late Nineteenth- and Early Twentieth-Century Spain. European History Quarterly, 35 (2), 241-265. Disponible en: https://doi.org/10.1177/0265691405051466.

Graham, H. (1996). Community, Nation and State in Republican Spain, 1931-1938. En C. Mar-Molinero y A. Smith (eds.). Nationalism and the Nation in the Iberian Peninsula (pp. 133-147). Oxford: Berg.

Grigorievs, A. (1996). The Baltic Predicament. En R. Caplan y J. Feffer (eds.). Europe's New Nationalism. States and Minorities in Conflict (pp. 120-137). Oxford: Oxford UP.

Hall, J. A. (2003). Conditions for National Homogenizers. En U. Ozkirimli (ed.). Nationalism and its futures (pp. 15-31). Basingstoke: Palgrave. Disponible en: https://doi. org/10.1057/9780230524187_2.

Halliday, F. (2000). The perils of community: reason and unreason in nationalist ideology. Nations and Nationalism, 6 (2), 153-171. Disponible en: https://doi.org/10.1111/j.13545078.2000.00153.x.

Hechter, M. (2000). Containing Nationalism. Oxford: Oxford UP.

Hernández Burgos, C. (2013). Franquismo a ras de suelo. Zonas grises, apoyos sociales y actitudes durante la dictadura. Granada. Universidad de Granada.

(2017). Franquismo suave. El nacionalismo banal y cotidiano de la dictadura. En F. Archilés y A. Quiroga (eds.). El nacionalismo banal en la España contemporánea. Granada: Comares [en prensa].

Holguín, S. (2003). República de ciudadanos. Cultura e identidad nacional en la España republicana. Barcelona: Crítica.

Humlebaek, C. (2006). La memoria de la Segunda República durante la transición a la democracia. En A. Egido (ed.). Memoria de la Segunda República. Mito y realidad (pp. 159-173). Madrid: Biblioteca Nueva.

Hutchinson, J. (2005). Nations as zones of conflict. Londres: Sage.

- (2006). Hot and Banal Nationalism: the Nationalization of «the Masses». En G. Delanty y K. Kumar (eds.). The Sage Handbook of Nations and Nationalism (pp. 295-306). Londres: Sage. Disponible en: https://doi.org/10.4135/9781848608061.n26.

— y Smith, A. D. (1996). Introduction. En J. Hutchinson y A. D. Smith (eds.). Ethnicity. $A$ reader (pp. 3-14). Oxford: Oxford UP.

Kissane, B. (2015). Introduction. En B. Kissane (ed.). After Civil War. Division, Reconstruction, and Reconciliation in contemporary Europe (pp. 1-16). Philadelphia: University of Pennsylvania Press.

Kramer, A. (2014). Asesinatos en masa y genocidio de 1914 a 1945: un intento de análisis comparativo. En J. Rodrigo (ed.). Políticas de la violencia. Europa, siglo XX (pp. 33-61). Zaragoza: Prensas de la Universidad de Zaragoza.

Langewiesche, D. (2012). La época del Estado nación en Europa. Valencia: PUV.

Louzao, J. (2010). El Sagrado Corazón de Jesús como instrumento de nacionalización (c. 1898-1939). En M. Esteban de Vega y M. D. de la Calle (eds.). Procesos de 
nacionalización en la España contemporánea (pp. 173-188). Salamanca: Universidad de Salamanca.

(2011). La Virgen y la salvación de España. Un ensayo de historia cultural durante la Segunda República. Ayer, 82 (2), 187-210.

- (2015). Las imágenes de lo sagrado o cómo ser católico entre cambios y continuidades (1875-1931). Historia Contemporánea, 51, 455-485. Disponible en: https://doi. org/10.1387/hc. 14718 .

— y Rodríguez Lago, J. R. (2016). Religión y nacionalización. Una aproximación desde la historia española. En F. Luengo y F. Molina (eds.). Los caminos de la nación. Factores de nacionalización en la España contemporánea (pp. 53-76). Granada: Comares.

Lowe, K. (2014). Savage Continent. Europe in the Aftermath of World War II. Londres: Penguin.

Malesevic, S. (2004). The Sociology of Ethnicity. Londres: Sage.

- (2013a). Is Nationalism intrinsecally Violent? Nationalism and Ethnic Politics, 19, 12-37. Disponible en: https://doi.org/10.1080/13537113.2013.761894.

- (2013b). Nation-States and Nationalisms. Cambridge: Polity Press.

(2013c). Obliterating heterogeneity through peace. Nationalisms, states and wars, in the Balkans. En J. A. Hall y S. Malesevic (eds.). Nationalism and War (pp. 255-276). Cambridge: Cambridge UP. Disponible en: https://doi.org/10.1017/CBO9781139540964.014.

Mann, M. (2009). El lado oscuro de la democracia. Un estudio sobre la limpieza étnica. Valencia: PUV.

Marín, M. (2006). Franquismo e inmigración interior: el caso de Sabadell (1939-1960). Historia Social, 56, 131-151.

- (2008). Familiares pero desconocidas. Las migraciones interiores durante el régimen franquista. En D. A. González (coord.). El franquismo y la transición en España (pp. 61-95). Madrid: La Catarata.

Martínez Sánchez, S. (2016). A por los rojos. Los párrocos de Jaén ante la depuración de maestros, funcionarios, vecinos y masones, 1939-1942. En F. Montero y J. Louzao (eds.). La restauración social católica en el primer franquismo, 1939-1953 (pp. 251-284). Granada: Comares.

Menozzi, D. (2013). Iglesia católica y nación en el período de entreguerras. En A. Botti, F. Montero y A. Quiroga (eds.). Católicos y patriotas. Religión y nación en la Europa de entreguerras (pp. 21-39). Madrid: Sílex.

Michonneau, S. (2014). Ruinas de guerra e imaginario nacional bajo el franquismo. En S. Michonneau y X. M. Núńez Seixas (eds.). Imaginarios y representaciones de España durante el franquismo (pp. 25-47). Madrid: Casa de Velázquez.

Miguez, A. (2014a). La naturaleza 'no política' del franquismo. Adaptación social y resiliencia. En L. Hernández y A. Artiaga (eds.). Otras miradas sobre golpe, guerra y dictadura (pp. 179-200). Madrid: La Catarata.

- (2014b). La genealogía genocida del franquismo. Violencia, memoria e impunidad. Madrid: Abada.

(2016). Introducción: 1961. Los términos del debate sobre la naturaleza de la violencia franquista. En A. Miguez (ed.). Ni verdugos ni victimas. Actitudes sociales ante la violencia. Del franquismo a la dictadura argentina (pp. 1-18). Granada, Comares. 
- y Molina, F. (2016). The persistence of the rural idyll. Peasant imagery, social change and nationalism in Spain, 1939-1978. European Review of History, 23 (4), 686-706. Disponible en: https://doi.org/10.1080/13507486.2016.1154929.

Molina, F. y Pérez, J. A. (2016). Violencia y nacionalización de masas: el franquismo. En F. Luengo y F. Molina (eds.). Los caminos de la nación. Factores de nacionalización en la España contemporánea (pp. 121-147). Granada: Comares.

Morales, A., Fusi J. P. y de Blas, A. (dirs.) (2013). Historia de la nación y del nacionalismo español. Madrid: Galaxia Gutemberg.

Moreno Luzón, J. y Núñez Seixas, X. M. (2017). Los colores de la patria. Simbolos nacionales en la España contemporánea. Madrid: Tecnos.

Moreno Seco, M. (2002). Creencias religiosas y política en la dictadura franquista. Pasado y Memoria, 1, 111-130. Disponible en: https://doi.org/10.14198/PASADO2002.1.05.

Moreno, R. (2014). Franquismo y nacionalismo español. Una aproximación a sus aspectos fundamentales. Hispania Nova, 14. Disponible en: http://e-revistas.uc3m.es/index. php/HISPNOV/article/view/2331.

- (2016). Pensar la nación desde la violencia: conceptos, teoría y dimensiones empíricas. En P. Hernández et al. (eds.). Las violencias y la historia (pp. 307-329). Salamanca: Hergar Ediciones Antema.

Núñez Seixas, X. M. (1999). Los nacionalismos en la España contemporánea (siglos XIX-Xx). Barcelona: Hipòtesi.

- (2006). ¡Fuera el invasor! Nacionalismos y movilización bélica durante la guerra civil española (1936-1939). Madrid: Marcial Pons.

- (2007a). Nuevos y viejos nacionalistas: la cuestión territorial en el tardofranquismo, 1959-1975. Ayer, 68 (4), 59-86.

- (2007b). De impuras naciones: historiografía reciente y cuestión nacional en España. Alcores, 4, 211-239.

- (2009). Nacionalismo español y franquismo. Una visión general. En M. Ortiz de las Heras (ed.). Culturas politicas del nacionalismo español (pp. 21-36). Madrid: La Catarata.

Ortega, T. (2006). «Se hace camino al andar». Balance historiográfico y nuevas propuestas de investigación sobre la dictadura franquista. Ayer, 63 (3), 259-278.

Ozkirimli, U. (2005). Contemporary Debates on Nationalism: A Critical Engagement. Basingstoke: Palgrave.

- y Uyan-Semerci, P. (2011). Pater familias and homo nationalis: Understanding nationalism in the case of Turquey. Ethnicities, 11 (1), 59-79. Disponible en: https:/doi. org/10.1177/1468796810388701.

Pla, D. (2007). 1939. En J. Canal (ed.). Exilios. Los éxodos políticos en la historia de España. (pp. 241-269). Madrid: Sílex.

Preston, P. (2011). El holocausto español. Odio y exterminio en la guerra civil y después. Madrid: Debate.

Quiroga, A. (2008). Haciendo españoles. La nacionalización de las masas en la Dictadura de Primo de Rivera. Madrid: CEPC.

— (2011a). La nacionalización en España una propuesta teórica. Ayer, 90 (2), 17-38. 
- (2011b). Hermanos de sangre. Regeneracionismo, catolicismo y racismo en los nacionalismos españoles, catalanes y vascos (1890-1945). En C. Gómez (ed.). Joaquín Costa y la modernización de España (pp. 629-659). Madrid: Congreso de los Diputados.

— (2016). La niña bonita pasea un león. Nacionalización de masas en el ámbito local: Alagón, 1931-1936. En F. Morente, J. Pomés y J. Puigsech (eds.). La rabia y la idea. Política e identidad en la España republicana (pp.317-341). Zaragoza: Prensas Universitarias de Zaragoza.

Radcliff, P. (1997). La representación de la nación. El conflicto en torno a la identidad nacional y las prácticas simbólicas en la Segunda República. En R. Cruz y M. Pérez Ledesma (eds.). Cultura y movilización en la España contemporánea (pp. 305-325). Madrid: Alianza Editorial.

Ramón Solans, F. J. (2015). «El catolicismo tiene masas». Nación, política y movilización en España, 1868-1931. Historia Contemporánea, 51 (2), 427-454. Disponible en: https:// doi.org/10.1387/hc.14716.

Richards, M. (2005). Presentando armas al Santísimo Sacramento: Guerra Civil y Semana Santa en la ciudad de Málaga. En C. Ealham y M. Richards (eds.). España fragmentada. Historia cultural y Guerra Civil española (pp. 253-286). Granada: Comares.

Rieffer, B. A. J. (2003). Religion and Nationalism. Understanding the consequences of a complex relationship. Ethnicities, 3 (2), 215-242. Disponible en: https://doi.org/10.117 7/1468796803003002003.

Rodrigo, J. (2008). Hasta la raiz. Violencia durante la Guerra Civil y la dictadura franquista. Madrid: Alianza.

— (2010). Barbarie: los presupuestos del exterminio. Historia Social, 66, 79-98.

- (2014). Heterofobia: las políticas de violencia en la Europa del Novecientos. En J. Rodrigo (ed.). Politicas de la violencia. Europa, siglo XX (pp. 9-31). Zaragoza: Prensas de la Universidad de Zaragoza.

— (ed.) (2014). Politicas de la violencia. Europa, siglo XX. Zaragoza: PUZ.

Rodríguez Barreira, O. (2013). Miserias del poder. Los poderes locales y el Nuevo Estado franquista, 1936-1951. Valencia: Universitat de València.

Rueda, J. C. (2014). Franquismo banal. España como relato televisivo, 1966-1975. En F. Archilés e I. Saz (eds.). Naciones y Estado. La cuestión española (pp. 225-244). Valencia: PUV.

Salomón, P. (2009). Republicanismo e identidad nacional española: la República como ideal integrador y salvífico de la nación. En C. Forcadell, I. Saz y P. Salomón (eds.). Discursos de España en el siglo XX (pp. 35-64). Valencia: PUV.

Sánchez Biosca, V. (2014). El NO-DO y la eficacia del nacionalismo banal. En S. Michonneau y X. M. Núñez Seixas (eds.). Imaginarios y representaciones de España durante el franquismo (pp. 177-195). Madrid: Casa de Velázquez.

Sánchez Erauskin, J. (1994). Por Dios hacia el imperio. Nacionalcatolicismo en las Vascongadas del primer franquismo. San Sebastián: R. B. Ediciones.

Sánchez Mosquera, M. (2008). Del miedo genético a la protesta. Memoria de los disidentes del franquismo. Barcelona: Fundación de Estudios Sindicales.

Sánchez Recio, G. (2015). La aniquilación de la República en la inmediata posguerra, 19391945. En G. Sánchez Recio y R. Moreno (eds.). Aniquilación a la República y castigo a la lealtad (pp. 23-63). Alicante: Publicacions Universitat d'Alacant. 
Saz, I. (2015). Las raíces culturales del franquismo. En M. Pérez Ledesma e I. Saz (coords.). Del Franquismo a la democracia, 1936-2013 (vol. IV de la Historia de las culturas politicas en España y América Latina — pp. 21-51-). Madrid: Marcial Pons.

- (2003). España contra España. Los nacionalismos franquistas. Madrid: Marcial Pons.

- (2009). Las Españas del franquismo. Ascenso y declive del discurso de nación. En C. Forcadell, I. Saz y P. Salomón (eds.). Discursos de España en el siglo XX. (pp. 147-164). Valencia: PUV.

Serrano, J. E. (2016). La exhumación de 1979 en Murcia. Acción colectiva de familiares de fusilados republicanos durante la transición. Ayer, 103 (3), 147-177.

Sevillano, F. (2007). Rojos. La representación del enemigo en la Guerra Civil. Madrid: Alianza. (2016). Política y criminalidad en el Nuevo Estado franquista. La criminalización del enemigo en el derecho penal de posguerra. Historia y Politica, 35, 289-311. Disponible en: https://doi.org/10.18042/hp.35.12.

Sirera, C. (2015). Neglecting the $19^{\text {th }}$ century. Democracy, the consensus trap and modernization theory in Spain. History of the Human Sciences, 28 (3), 51-67. Disponible en: https://doi.org/10.1177/0952695115579588.

Snyder, T. (2003). The Reconstruction of Nations. Poland, Ukraine, Lithuania, Belarus, 15691999. Yale: Yale UP.

- (2012). Savagery. New Republic, 29-3-2012. Disponible en: https://newrepublic.com/ article/102134/spanish-holocaust-francisco-franco.

Thiesse, A. M. (2010). La creación de las identidades nacionales. Europa, siglos XVIII-XX. Madrid: Ezaro.

Ugarte, J. (1998). La nueva Covadonga insurgente. Origenes sociales y culturales de la sublevación de 1936 en Navarra y el País Vasco. Madrid: Biblioteca Nueva.

Vinyes, R. (2002). Irredentas. Las presas politicas y sus hijos en las cárceles de Franco. Barcelona: Temas de Hoy.

- (2011). Doblegar y transformar: la industria penitenciaria y sus encarceladas políticas. Studia Historica. Historia Contemporánea, 29, 35-54.

- Armengou, M. y Belis, R. (2002). Los niños perdidos del franquismo. Barcelona: RBA.

White, G. H. (2000). Nationalism and Territory. Constructing Group Identity in Southeastern Europe. Lanham: Rowman and Littlefield Publishers.

Wimmer, G. (2006). Ethnic Exclusion in Nationalizing States. En G. Delanty y K. Kumar (eds.). The Sage Handbook of Nations and Nationalism (pp. 334-344). Londres: Sage. Disponible en: https://doi.org/10.4135/9781848608061.n29.

Yosmaoglu, Y. (2014). Blood ties. Religion, Violence and Politics of Nationhood in Ottoman Macedonia, 1878-1908. Ithaca: Cornell UP. 